\title{
Significance of Wood Anatomical Features to the Taxonomy of Five Cola Species
}

\author{
Akinloye A. J. ${ }^{1}$, Illoh H. C. ${ }^{1} \&$ Olagoke O. A. ${ }^{2}$ \\ ${ }^{1}$ Department of Botany, Obafemi Awolowo University, Ile-Ife, Osun State, Nigeria \\ ${ }^{2}$ Department of Forestry and Wood Technology, Federal University of Technology, Akure, Ondo State, Nigeria \\ Correspondence: Akinloye A. J., Department of Botany, Obafemi Awolowo University, Ile-Ife, Osun State, \\ Nigeria. Tel: 234-708-650-6868. E-mail: akinloye_johnson@yahoo.com
}

Received: November 29, 2011 Accepted: March 16, 2012 Online Published: July 6, 2012

doi:10.5539/sar.v1n2p21

URL: http://dx.doi.org/10.5539/sar.v1n2p21

\begin{abstract}
Wood anatomy of five Cola species was investigated to identify and describe anatomical features in search of distinctive characters that could possibly be used in the resolution of their taxonomy. Transverse, tangential and radial longitudinal sections and macerated samples were prepared into microscopic slides. Characteristic similarity and disparity in the tissues arrangement as well as cell inclusions were noted for description and delimitation. All the five Cola species studied had essentially the same anatomical features, but the difficulty posed by the identification of Cola acuminata and Cola nitida when not in fruit could be resolved using anatomical features. Cola acuminata have extensive fibre and numerous crystals relative to Cola nitida, while Cola hispida and Cola millenii are the only species having monohydric crystals. Cola gigantica is the only species that have few xylem fibres while other species have extensive xylem fibre. These features have proved very functional and strongly of diagnostic value in the classification and delimitation of the studied Cola species.
\end{abstract}

Keywords: wood anatomy, cola species, anatomical features, identification, diagnostic value, species delimitation

\section{Introduction}

The genus Cola, belonging to the family Sterculiaceae, it is indigenous to West Tropical Africa. Members of the genus are evergreen trees of the forest, mostly small or moderate in size with the exception of a few which rise to some height (Russell, 1955). Cola is distinctive from Sterculia, a closely related genus, on the basis of flower and fruit character, Cola has anthers regularly arranged in a double or single ring round the base of the ovary in the hermaphrodite flower or on synantherous in the male flowers (Russell, 1955). Cola fruit is dehiscent, i.e. the pod has line through which it break open. The seed is normally without endosperm. Most of the species of Cola have seeds which are hard and inedible. Those Cola with edible seeds, designated into sub-genus Encola, are comparatively few and probably referable to six species (Russell, 1955). The species of Cola with edible seeds are mostly larger and more robust trees.

Cola (especially C. nitida Schott and Endl, C. acuminata (P. Beaiv) Schott and Endl and C. verticillata) is a crop plant of hot tropical lowland forest with a rainfall extending over a period of 8 months or more and a temperature of between $23^{\circ} \mathrm{C}$ and $28^{\circ} \mathrm{C}$. It needs deep and well drained soil and thrives in sheltered valleys on the fringes of forest relic where such soil rich in humus occur (Quarcoo, 1977). It grows to a height of between $4.5 \mathrm{~m}$-and 18 $\mathrm{m}$, developing either a robust or slender stem with either sparse or bushy foliage.

Although Oyebade (1973) described only Cola nitida and C. acuminata as the Nigerian economic Cola species out of the over 50 species recorded in West Africa, C. verticillata and C. anomala are also well recognized in the Nigerian Cola market. These popularly known species are cultivated in Nigeria mainly for their nuts, which contain some alkaloids (caffeine, theobromine and kolanin). Because these alkaloids dispel sleep, thirst and hunger, the nuts are used widely as masticator.

Meanwhile, Cola of global popular trade is Cola nitida. Nigeria produces $88 \%$ of the world C. nitida crop. Of this total, $90 \%$ is consumed within the country mainly in the Kola chewing area of the northern states while $10 \%$ only is exported (Quarcoo, 1977). A few hundred tons of the dried nuts are exported annually from West Africa to North America and Europe where they are used for beverages and pharmaceuticals (Oyebade, 1973). 
Several authors have studied the taxonomy of this genus and rearranged species in subgenera with the latest revision made in 1962. In addition, much has been written on the propagation, cultivation, pathology (both field and store pathology) and marketing of $C$. nitida and C. acuminata seeds, but publications on the wood anatomy of any of the species in this genus are comparatively rarer. Therefore, this work was undertaken to identify and describe anatomical features of five Cola species in search of distinctive characters of high diagnostic values that could possibly be used to resolve the taxonomy of the studied taxa.

\section{Materials and Methods}

\subsection{Collection and Preparation of Wood Samples}

Samples of C. acuminata and C. nitida were collected from Awosun Village in Osun State of Nigeria ( $+7^{`} 30^{`} 4.49$; $\left.+4^{`} 27^{`} 25.54\right)$, while samples of $C$. gigantea Ache, $C$. hispida Brenan and Keay and C. millenii Schum were collected from Onigambari Forest Reserve, Ogun State of Nigeria (+7`9`25.96; +3`52`44.37). The collection for this study was made both in the rainy and dry seasons of 2004 to establish if there exists any seasonal variation in their anatomical features. Matured wood of collected Cola species were cut into cubes dimensions of $1 \times 1 \times 1 \mathrm{~cm}^{3}$ and preserved in fixative ( $50 \%$ ethanol).

\subsection{Sectioning and Staining of Wood Samples' Sections}

From these samples, three differently orientated sections \{transverse section (TS); tangential longitudinal section (TLS); and radial longitudinal section (RLS)\} were cut at 10 microns thickness using sledge microtome. Each section was stained for 3 minutes in Safranin O and counter stained in Alcian blue. The stained sections were washed/ rinsed in water before treatment in a series of ethanol solutions $(50 \%, 70 \%, 90 \%$ and $100 \%)$ to remove water molecules (dehydration process) and to remove excess stain (differentiation process). The dehydrated and differentiated sections were transferred into absolute xylene in two series to remove last trace of water, to clear the section (making it more transparent) and to remove the last traces of ethanol. Each section was mounted on a glass slide in DPX ${ }^{\circledR}$ mountant.

\subsection{Maceration and Staining of Wood Samples' Macerates}

Wood samples from each of the Cola species were sliced into small pieces using pen knife and macerated using Schultz's fluid obtained by mixing equal volume of $10 \%$ chronic acid [dissolved 1 gm Potassium Nitrate $\left(\mathrm{KNO}_{3}\right)$ in $50 \mathrm{ml}$ Conc. Nitric Acid $\left.\left(\mathrm{HNO}_{3}\right)\right]$ and $10 \%$ nitric acid. The maceration was carried out in beaker kept in the oven at $90^{\circ} \mathrm{C}$ for 8 hours. The macerated wood samples were washed in five changes of water and stained using the same procedure as employed for the sections.

\subsection{Microscopy}

Microscopic observation of each slide was made and recorded. Photomicrographs of the slides were made using photomicroscope. Tissues and cells identification and description was done according to Metcalfe and Chalk (1989), Esau (1977), Cutter (1978), Bilgrami et al. (1983) and Fahn (1977).

\section{Results}

\subsection{Unifying Anatomical Features of the Studied Cola Species}

The results of the microscopic investigation of Cola species' stem sections revealed that secretory ducts were present in the piths of all taxa (Figures 1a, 2a, 3a, 4a and 5a). Their woods were characterized by the presence of diffuse pores with small and large vessels interspersed solitarily. These vessels were occasionally clustered and in radial multiples of 2-6 pores. Vessel pores were elliptic, oval to circular in the transverse plane. Tyloses were conspicuous in a few vessels only in the transverse plane. Perforation plates were, however, simple and scalariform, and had an oblique inclination in the transverse plane with either a very short or no tail in the tangential and radial planes. The xylem parenchymas were paratracheal, aliform-confluent (Figures 1b, 2b, 3b, $4 \mathrm{~b}$ and $5 \mathrm{~b}$ ). Rays were non-storeyed, with both uniseriate and multiseriate rays. Rays appeared as hexagonal elongated cells in the tangential plane. In radial plane they are heterogeneous upright and procumbent forms, though multiseriate rays were predominant (Figures 1c, 2c, 3c, 4c and 5c). Druses and monohydric crystal sands were present and were numerous in the ray cells, pith and parenchyma cells. Styloids wre also present in the parenchyma and ray cells and among the fibres (Figures 1d, 2d, 3d, 4d and 5d). The presence of secretory canals in the pith was also noteworthy. The fibres were extensive, non-storeyed, non-septate and not pitting with the pointing ends having thick walls and large lumens. 

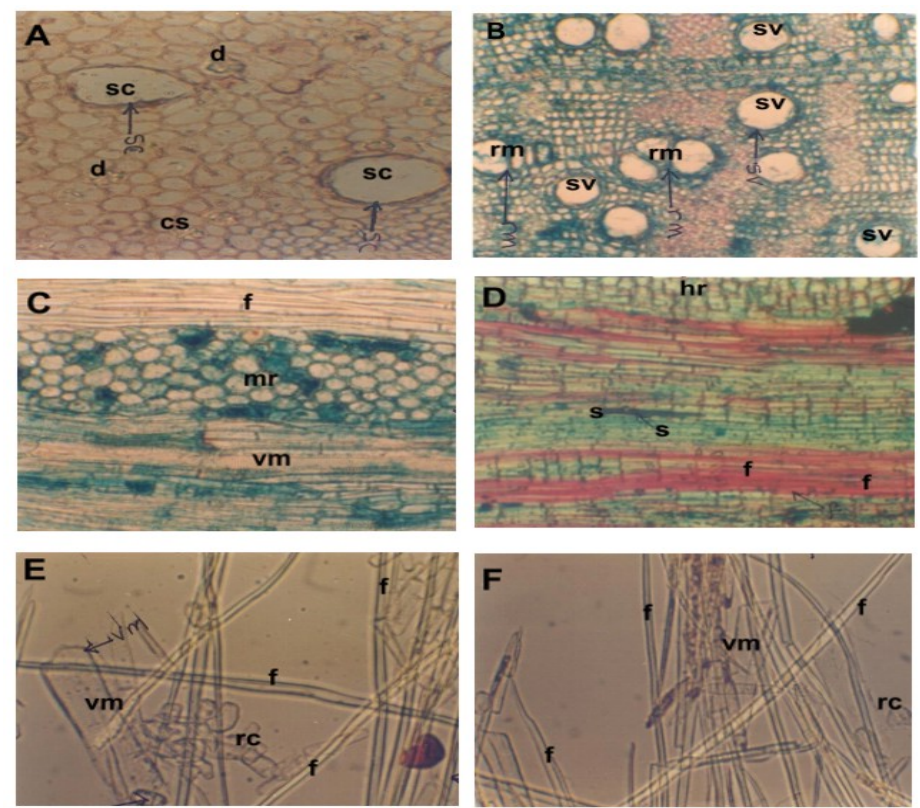

Figure 1. Sections and macerates of Cola acuminate

A \& B: Transverse Sections (TS) of stem- pith and xylem wood respectively.

C: Tangential Longitudinal Section (TLS) of stem wood; D: Radial Longitudinal Section (RLS) of stem wood.

E \& F: Macerates of stem wood showing isolated wood cells.

Key: $\mathrm{cs}=$ crystal sands; $\mathrm{d}=$ druses; $\mathrm{f}=$ fibre; $\mathrm{hr}=$ heterogenous rays; $\mathrm{mr}=$ multiseriate rays; $\mathrm{rc}=$ ray cell;

$\mathrm{rm}=$ radial multiple; $\mathrm{s}=$ styloid; $\mathrm{sv}=$ solitary vessel; $\mathrm{vm}=$ vessel member

\subsection{Discriminative Anatomical Features of the Studied Cola Species}

C. acuminata wood was distinct having more extensive fibres with an average fibre length of $1325 \mu \mathrm{m}$ (Figure 1e and 1f). C. gigantea, however, had a greater number of vessels compared to C. acuminata and C. nitida and more crystal sands than any of the species studied (Figure 2a); it had a mean fibre length of $2050 \mu \mathrm{m}$ (Figures 2e and 2f) and the secretory canals were the largest of all species studied. C. hispida had radial multiple vessels of not more than three pores (Figure 3b), the longest rays, the most abundant fibre content and average fibre length of $1925 \mu \mathrm{m}$ (Figure 3e \& f) radialmultiple vessels were rarely not more than two pores in C. millenii and wood from this species was futher characterized by the presence of square or rectangular shaped crystals, fibre extension following that of $C$. hispida and an average fibre length of $1650 \mu \mathrm{m}$ (Figures $4 \mathrm{e}$ and $4 \mathrm{f}$ ). Wood of $C$. nitida was characterised by the-presence of scanty druses in the pith parenchyma cells (Figure 5a) and had a mean fibre length of $1375 \mu \mathrm{m}$ (Figures 5e and 5f). 

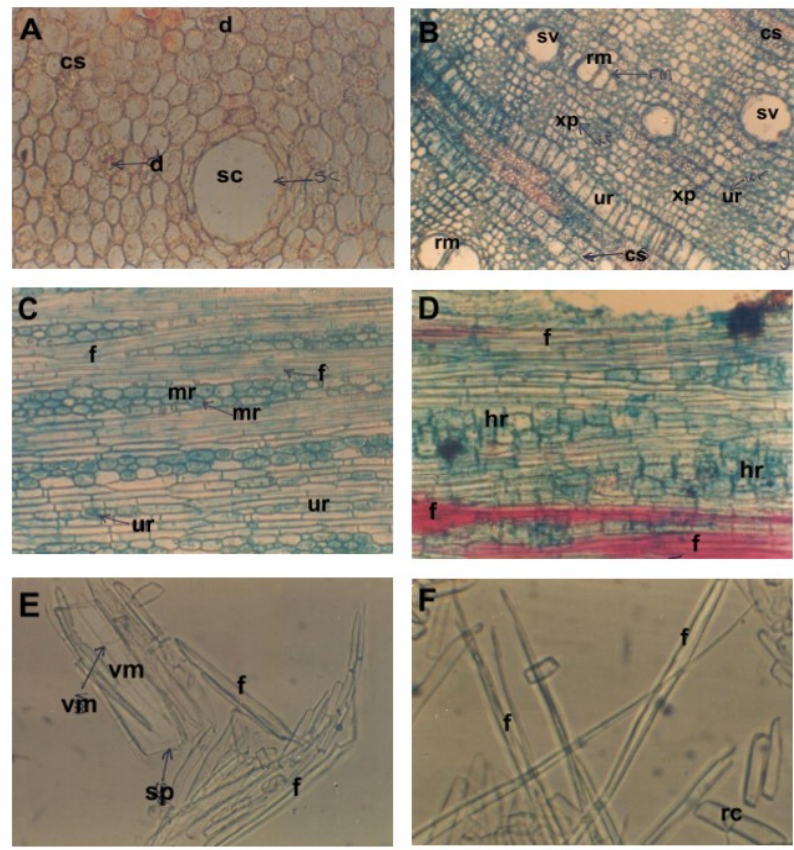

Figure 2. Sections and macerates of Cola gigantean

A \& B: Transverse Sections (TS) of stem- pith and xylem wood respectively.

C: Tangential Longitudinal Section (TLS) of stem wood; D: Radial Longitudinal Section (RLS) of stem wood.

E \& F: Macerates of stem wood showing isolated wood cells.

Key: $\mathrm{cs}=$ crystal sands; $\mathrm{d}=$ druses; $\mathrm{f}=$ fibre; $\mathrm{hr}=$ heterogenous rays; $\mathrm{mr}=$ multiseriate rays; $\mathrm{rc}=$ ray cell;

$\mathrm{rm}=$ radial multiple; $\mathrm{s}=$ styloid; $\mathrm{sp}=$ simple perforation; $\mathrm{sv}=$ solitary vessel; $\mathrm{ur}=$ uniseriate ray;

$\mathrm{vm}=$ vessel member; $\mathrm{xp}=\mathrm{xylem}$ parenchyma.
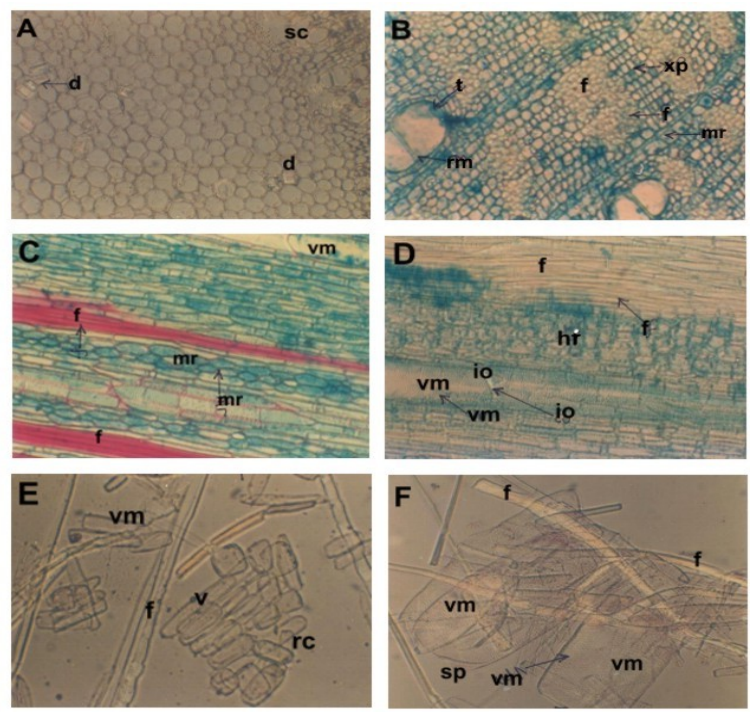

Figure 3. Sections and macerates of Cola hispida

A \& B: Transverse Sections (TS) of stem- pith and xylem wood respectively.

C:Tangential Longitudinal Section (TLS) of stem wood; D: Radial Longitudinal Section (RLS) of stem wood.

$\mathrm{E} \& \mathrm{~F}$ : Macerates of stem wood showing isolated wood cells.

Key: $\mathrm{cs}=$ crystal sands; $\mathrm{d}=$ druses; $\mathrm{f}=$ fibre; $\mathrm{hr}=$ heterogenous rays

io = inclination oblique; $\mathrm{mr}=$ multiseriate rays; $\mathrm{rc}=$ ray cell; $\mathrm{rm}=$ radial multiple; $\mathrm{s}=\mathrm{styloid}$;

$\mathrm{s} p=$ simple perforation; $\mathrm{sv}=$ solitary vessel; $\mathrm{ur}=$ uniseriate ray; $\mathrm{vm}=$ vessel member;

$\mathrm{xp}=\mathrm{xylem}$ parenchyma. 

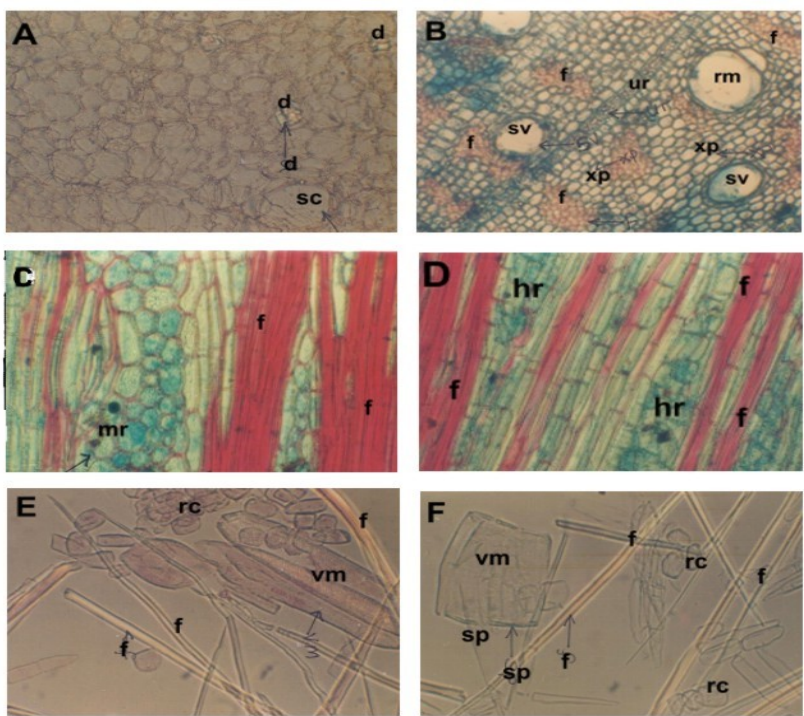

Figure 4. Sections and macerates of Cola millenii

A \& B: Transverse Sections (TS) of stem- pith and xylem wood respectively.

C: Tangential Longitudinal Section (TLS) of stem wood; D: Radial Longitudinal Section (RLS) of stem wood.

E \& F: Macerates of stem wood showing isolated wood cells.

Key: $\mathrm{cs}=$ crystal sands; $\mathrm{d}=$ druses; $\mathrm{f}=$ fibre; $\mathrm{hr}=$ heterogenous rays; $\mathrm{mr}=$ multiseriate rays; $\mathrm{rc}=$ ray cell; $\mathrm{rm}=$ radial multiple; $\mathrm{s}=$ styloid; $\mathrm{sp}=$ simple perforation; $\mathrm{sv}=$ solitary vessel; $\mathrm{ur}=$ uniseriate ray; $\mathrm{vm}=$ vessel member; $\mathrm{xp}=\mathrm{xylem}$ parenchyma.
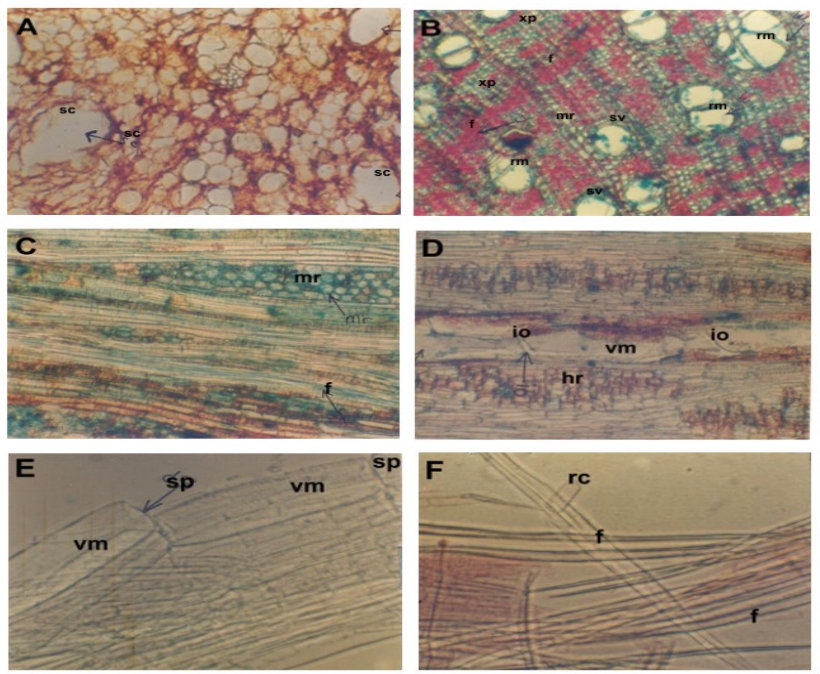

Figure 5. Sections and macerates of Cola nitida

A \& B: Transverse Sections (TS) of stem- pith and xylem wood respectively.

C: Tangential Longitudinal Section (TLS) of stem wood; D: Radial Longitudinal Section (RLS) of stem wood.

E \& F: Macerates of stem wood showing isolated wood cells.

Key:cs= crystal sands; $\mathrm{d}=$ druses; $\mathrm{f}=$ fibre; $\mathrm{hr}=$ heterogenous rays; io = inclination oblique; $\mathrm{mr}=$ multiseriate rays; $\mathrm{rc}=$ ray cell; $\mathrm{rm}=$ radial multiple; $\mathrm{s}=$ styloid; $\mathrm{sp}=$ simple perforation; $\mathrm{sv}=$ solitary vessel; $\mathrm{ur}=$ uniseriate ray; $\mathrm{vm}=$ vessel member; $\mathrm{xp}=\mathrm{xylem}$ parenchyma.

\section{Discussion}

The wood anatomy of the five species of Cola had more classificatory characteristics than delimiting specific characters. The study showed that all taxa have a high degree of multiseriate and low degree of uniseriate rays; non-storeyed vessels with simple and scalariform perforated walls, solitary vessels, radial pore multiple and 
paratracheal aliform confluent parenchyma. The presence of tyloses in vessels, as observed in this work, was also more of classificatory value than delimiting as mentioned by Metcalf and Chalk (1989) in the family Sterculiaceae and Dickson (1972) in the family Connaraceae.

The discriminatory value of fibre characteristics in distinguishing the Cola species cannot be overemphasized in this study. Though the $C$. hispida fibre coverage is the most extensive of all the species, $C$. gigantea conversely has the longest fibre $( \pm 2050 \mu \mathrm{m})$, followed by $C$. hispida $( \pm 1925 \mu \mathrm{m}) ; C$. millenii, $( \pm 1650 \mu \mathrm{m}) ; C$. nitida $( \pm$ $1375 \mu \mathrm{m})$ and $C$. acuminata $( \pm 1325 \mu \mathrm{m})$. One might conclude from this observation that the length and extensiveness of fibre seem to be taxon specific, and thus, there is no correlation between length and extensiveness of fibre except in C. hispida, which had the highest degree of fibre extensiveness and as well as a relatively high mean fibre length $( \pm 1925 \mu \mathrm{m})$.

The use of crystals as diagnostic tool have been extensively discussed by Amos (1951), Terwelle (1976), and Illoh and Inyang (1998). The presence of Styloids and crystals was a common feature for all species studied, but crystal sands were more abundant in C. acumunata than in C. nitida. Crystals described by Metcalfe and Chalk (1989) as monohydric crystals commonly occurred in C. millenii and C. hispida, but were more abundant in the latter than in the former. A similar observation (i.e. abundance) by Dickson (1972) was used in distinguishing taxa in the family Connaraceae. The crystals are however borne in crystalliferous fibres, axial and xylem parenchyma, parenchyma cells of the pith, ray and cambium.

Moreover, the location, size and the number of secretory ducts are among certain features that can be used to delimit some of the species. Secretory ducts situated in the pith and xylem are common features in all the taxa, although Cola gigantea has comparatively wider ducts relative to the other species. This distinguishing characteristic observed in this work was not recorded by Metcalfe and Chalk (1989) in their general discussion on the family Sterculiaceae.

\section{Conclusion}

Wood anatomical features have been proven to have classificatory and diagnostic values highly significant to the taxonomy of the five Cola species studied. Many features tend to unify them than those that can be used to delimit them. Meanwhile, C. acuminata and C. nitida that are difficult to distinguish when not in fruit can be distinguished anatomically since $C$. acuminata have more extensive fibre and more abundant crystal sand than $C$. nitida.

\section{References}

Amos, G. (1951). Some silicious timber of British Guyana. Carrib. For, 1(1), 33-37.

Bilgrami, K. S., Srivastava L. M., \& Shreemali, J. L. (1983). Fundamentals of Botany. Shahdara, Delhi (India), Vikas Publishing House PVT Ltd. pp. 563-689.

Cutter, E. G. (1978). Plant Anatomy Part 1: Cells and Tissues (2nd ed.). London, William Clowes and Sons Ltd pp. 69-77, 78-93, 144-169.

Dickson, W. C. (1972). Anatomy Studies in the Family Connaraceae II. Wood Anatomy. The Journal of the Mitchell Society, 117-136.

Esau, K. (1977). Anatomy of Seed Plnts (2nd ed.), New York, John Wiley and Sons, 125-143.

Fahn, A. (1977). Plant Anatomy (2nd ed.). NewYork, Pergamon Press, pp. 310-350.

Illoh, H. C., \& Inyang, U. E. (1998). Foliar epidermis and petiole anatomy in some Nigerian Solanum Linn. Species in the sub-genus Leptostemonum (BITT) DUN. Glimpses in Plant Research, 12, 73-86.

Metcalfe, C. R., \& Chalk, L. (1989). Anatomy of the Dicotyledons (2nd ed.). Oxford, Charendon Press. pp. 1-46, 298-308.

Oyebade, T. (1973). Some aspects of developmental physiology of Nigerian Kola (Cola nitida) fruit. Economic Botany, 2, 417-422. http://dx.doi.org/10.1007/BF02860695

Quarcoo, T., Cola, C., \& Verticillata, C. (1977). An Agricultural Note Book, Ibadan Nigeria, CRIN Press.

Russell, T. A. (1955). The Kola of Nigeria and the Cameroon. Tropical Agriculture, Trin, 32(3), 211-277.

Terwelle, B. J. H. (1976). Silica grains in woody plants in neotropic especially Surinam. Leid. Bot. Ser, 3, 107-142. 